\title{
Editorial to volume 72 issue 2
}

\section{Anandaraj ${ }^{1,2}$}

(c) Indian Phytopathological Society 2019

Dear Readers,

The on line version of the second issue of volume 72:2 (June 2019) of Indian Phytopathology is already available and the print version is now ready. In this issue, there are 22 articles including two short communications.

The best way to manage any disease is by deploying resistance genes by locating resistance, screening for resistance, understanding the mechanism of resistance and evolving resistant varieties. In this issue the articles cover all these topics. Epidemiology, characterization of pathogens and developing rapid detection methods are part of strategies to combat plant diseases. The article on the use of metabolomics to understand the disease susceptible and resistant lines makes an interesting reading and the role of 'Omics' sciences to elucidate the mechanism of resistance. The new tools available enable us to understand the multifarious activities of biocontrol agents like nutrient mobilization and activating the microbiome of the rhizosphere. The antagonistic fungus Trichoderma is now recognized as an endophyte and its ability to modulate internal defense of plants. In this issue the article on Drechslera dactyloides and Dactylaria brochopaga are reported to enhance growth in tomato in addition to activating defense related enzymes.
There are five articles on characterization of pathogens, four articles on disease management including biological control, three each on resistance and epidemiology, two articles on fungicides and one each on arbuscular mycorrhizal fungi, antifungal botanical and one on virus detection.

There are five articles each on vegetable crops and cereals. The vegetable crops are potato, tomato, bitter-guard, brinjal and French-beans. The cereals included maize, wheat, barley, rice and pearl millet. Four fruits crops are ber, grapes, mango, pome and stone fruits. Other crops include, sun flower, cotton, Napier grass, lucky bamboo.

The editorial team has been making earnest efforts to bring the publication of Indian Phytopathology on time. I would like to express my sincere thanks to the authors, reviewers, editorial team, the executive council of Indian Phytopathological Society and business manager for all their help.

Publisher's Note Springer Nature remains neutral with regard to jurisdictional claims in published maps and institutional affiliations.
M. Anandaraj

arajiisr@gmail.com

Indian Phytopathological Society, New Delhi, India

2 Bangalore, India 